\title{
Molecular beacon-based real-time PCR detection of primary isolates of Salmonella Typhimurium and Salmonella Enteritidis in environmental and clinical samples
}

\author{
Andreas V Hadjinicolaou ${ }^{\dagger 1}$, Victoria L Demetriou ${ }^{\dagger 1}$, Maria A Emmanuel ${ }^{1,2}$, \\ Charalambos K Kakoyiannis ${ }^{2}$ and Leondios G Kostrikis*1
}

\begin{abstract}
Address: ${ }^{1}$ Department of Biological Sciences, University of Cyprus, Nicosia, Cyprus and ${ }^{2}$ Department of Veterinary Services, Ministry of Agriculture, Natural Resources and Environment, Nicosia, Cyprus

Email: Andreas V Hadjinicolaou - ah499@cam.ac.uk; Victoria L Demetriou - victoria.demetriou@ucy.ac.cy;

Maria A Emmanuel - emgenic@logos.cy.net; Charalambos K Kakoyiannis - director@vs.moa.gov.cy; Leondios G Kostrikis* - lkostrik@ucy.ac.cy

* Corresponding author †Equal contributors
\end{abstract}

Published: 19 May 2009

BMC Microbiology 2009, 9:97 doi:10.1186/147/-2180-9-97

This article is available from: http://www.biomedcentral.com/I47I-2180/9/97

(c) 2009 Hadjinicolaou et al; licensee BioMed Central Ltd.

This is an Open Access article distributed under the terms of the Creative Commons Attribution License (http://creativecommons.org/licenses/by/2.0), which permits unrestricted use, distribution, and reproduction in any medium, provided the original work is properly cited.
Received: 23 October 2008
Accepted: 19 May 2009

\begin{abstract}
Background: A fast and simple two-step multiplex real-time PCR assay has been developed to replace the traditional, laborious Salmonella serotyping procedure. Molecular beacons were incorporated into the assay as probes for target DNA. Target sequences were regions of the invA, prot6E and fliC genes specific for Salmonella spp. Salmonella Enteritidis and Salmonella Typhimurium, respectively, the two most clinically relevant serotypes. An internal amplification positive control was included in the experiment to ensure the optimal functioning of the PCR and detect possible PCR inhibition. Three sets of primers were used for the amplification of the target sequences. The results were compared to those of the Kauffmann-White antigenic classification scheme.
\end{abstract}

Results: The assay was 100\% sensitive and specific, correctly identifying all 44 Salmonella strains, all 2 I samples of S. Enteritidis and all 17 samples of S. Typhimurium tested in this work. Therefore, the entire experiment had specificity and sensitivity of $100 \%$. The detection limit was down to 10 copies of DNA target per $25 \mu$ reaction.

Conclusion: The assay can amplify and analyse a large number of samples in approximately 8 hours, compared to the 4 to 5 days conventional identification takes, and is thus considered a very promising method for detecting the two major serotypes of Salmonella quickly and accurately from clinical and environmental samples.

\section{Background}

Salmonella is a gram-negative, facultative anaerobic, flagellated bacterium. It is the pathogenic agent of salmonellosis, a major cause of enteric illness and typhoid fever, leading to many hospitalisations and a few rare deaths if no antibiotics are administered. Salmonella outbreaks are linked to unhygienic food preparation, cooking, reheating and storage practices. The bacterium can be isolated from raw meat and poultry products as well as from milk and milk-based products [1]. The detection of Salmonella therefore remains a highly important issue in microbiological analysis for food safety and standards. 
Because the nomenclature for the Salmonella genus is at times confusing, this publication will follow the current literature [2,3]. The CDC [3] distinguishes two Salmonella species (or subgenera): S. enterica and S. bongori. S. enterica is further divided into six subspecies, of which $S$. enterica subsp. enterica is the most clinically significant, causing $99 \%$ of Salmonella infections. In the present study we are concerned with its two main serovars: Salmonella enterica serovar Typhimurium (group D) denoted S. Typhimurium, and Salmonella enterica serovar Enteritidis (group B) denoted $S$. Enteritidis, which are the most commonly isolated Salmonellae from food-borne outbreaks.

Identification of the disease-causing Salmonella serovars is currently a lengthy process, and its initial isolation from food samples can be difficult as the bacteria can be present in small numbers and many closely related bacteria may be found within the same sample [4]. For this reason, preenrichment steps are required for all samples [5,6]. The current accepted method for isolation of Salmonella from foodstuffs is a well established procedure - ISO 6579, laborious and time-consuming, taking up to 5 days to complete $[7,8]$. The most widely-used method used to characterise Salmonella into its subspecies is the Kauffman-White serotyping system [9], based on the variability of the $\mathrm{O}, \mathrm{H}$ and $\mathrm{Vi}$ antigens [9-11]. Apart from being arduous, this method can not identify a small number of $S$. enterica samples that lack either the $\mathrm{O}$ antigen alone or both the $\mathrm{O}$ and the $\mathrm{H}$ antigens [12]. Therefore there is a need for fast, sensitive and specific "in the field" detection, using nucleic acid-based technologies such as molecular beacon-based real-time PCR, to reduce the time needed to complete the assay, but also improve the level of accuracy and reliability.

In this study, molecular beacons [13-15] and real-time PCR technology are combined to develop a fast, sensitive, clear-cut method of detection of Salmonella spp. and its two most clinically significant serotypes from clinical, food and environmental specimens, which reduces the time taken to identify the Salmonella strain from an environmental sample, and is precise enough to distinguish between serovars. PCR-based methods targeting various genes are usually more rapid and sensitive than culturebased methods, and the high specificity and high sensitivity of molecular beacons means they can be successfully combined with real-time PCR assays, and so provide a quick, accurate method for detection and analysis, making them ideal for routine diagnosis. Recent studies show that real-time PCR is gradually replacing gel electrophoresis [16-24] as it is suitable for large numbers of samples and involves automatic and fast analysis, as well as being able to execute multiplex protocols. Also, like in all probebased assays, molecular beacons offer additional specificity. Recent studies have employed molecular beacons in PCR for the detection of Salmonella [25-27].
Here the detection of Salmonella and the discrimination between $S$. Typhimurium and $S$. Enteritidis serotypes is done by targeting 133-136 nt regions of three genes, while an artificial internal amplification control (IAC) is also incorporated. The target for Salmonella spp is invA, as it is highly conserved in almost all Salmonella serotypes $[28,29]$, and its specificity is apparent from its continuous use in previous studies [18,24,28,30-43]. The target for the specific detection of $S$. Enteritidis is prot6E, whose absence from $S$. Enteritidis strains appears to be very rare [18], and the fliC gene has been chosen as a single target for the presence of $S$. Typhimurium. The method described here for the detection of Salmonella spp. from environmental and food specimens, not only reduces the time taken to identify the Salmonella strain, but is also precise enough to distinguish between its clinically significant serovars.

\section{Methods \\ Bacterial samples}

The primary Salmonella samples used in this study (Table 1) were obtained from various animal, food and environmental sources at the Cyprus Veterinary Services (Ministry of Agriculture, Natural Resources and Environment, Nicosia, Cyprus), which is the National Reference Laboratory of Salmonella for Cyprus. The commercially available bacterial strains listed in Table 2 were obtained from the American Type Culture Collection (ATCC, Manasas, USA), the National Collection of Type Cultures (NCTC, Health Protection Agency, London, UK) and MERCK KGaA (Darmstadt, Germany). The reference S. enterica serovars listed in Table 3 were obtained from the Community Reference Laboratory for Salmonella at the National Institute for Public Health and the Environment (RIVM, Bilthoven, the Netherlands). Thirty-eight $S$. Typhimurium and $S$. Enteritidis samples as well as six different Salmonella serovars have been incorporated to ensure that the assay could correctly identify and differentiate between serotypes of $S$. enterica. Eighteen non-Salmonella bacterial samples were also included to ensure accurate experimental design and specificity to the Salmonella genus.

\section{Bacterial cultures and serotyping}

The detection of Salmonella spp. was performed based on the ISO 6579:2002 method. In brief, $25 \mathrm{~g}$ of clinical specimen ( $10 \mathrm{~g}$ in the case of minced meat in accordance with the EC regulation 2073/2005 - Microbiological Criteria for Foodstuffs) were added to $225 \mathrm{ml}$ of buffered peptone water in a Stomacher ${ }^{\circledR}$ bag, sealed and placed in a Stomacher ${ }^{\circledR}$ blender for $3 \mathrm{~min}$. The blended sample was incubated for $18 \mathrm{~h}$ at $37^{\circ} \mathrm{C}$ and a $0.1 \mathrm{ml}$ aliquot of sample was inoculated into $10 \mathrm{ml}$ Rappaport-Vassiliadis medium with Soya (RVS) and into $10 \mathrm{ml}$ Muller-Kauffmann tetrathionate/novobiocin (MKTTn) broth; these cultures were incubated for $24 \mathrm{~h}$ at $41.5^{\circ} \mathrm{C}$ and $37^{\circ} \mathrm{C}$, respectively. Each culture was inoculated into xylose lysine deoxycho- 
Table I: Primary Bacterial Strains ${ }^{a}$

\begin{tabular}{|c|c|c|}
\hline Bacterial strain & Sample ID & Source of Sample \\
\hline Salmonella Enteritidis & CVS-140/I & Intestine from beef \\
\hline Salmonella Enteritidis & CVS-14I/I-5 & Liver \& ovaries from egg layer hens \\
\hline Salmonella Enteritidis & CVS-4054/I & Lymph ganglions \\
\hline Salmonella Enteritidis & CVS-4311/I & Intestine from canaries \\
\hline Salmonella Enteritidis & CVS-4325/4, 5 & Skin from neck of chicken \\
\hline Salmonella Enteritidis & CVS-442I/I & Fish food \\
\hline Salmonella Enteritidis & CVS-45I6/I & Veal \\
\hline Salmonella Enteritidis & CVS-4532/I & Parrot \\
\hline Salmonella Enteritidis & CVS-4540/I & Parrot \\
\hline Salmonella Enteritidis & CVS-4666/I & Faeces from egg layer hens \\
\hline Salmonella Enteritidis & CVS-4756/I & Faeces from hens farmed for meat \\
\hline Salmonella Enteritidis & CVS-4807//I-3 & Skin from neck of chicken \\
\hline Salmonella Enteritidis & CVS-4809/2 & Skin from neck of chicken \\
\hline Salmonella Enteritidis & CVS-4980/I & Faeces from chicken \\
\hline Salmonella Enteritidis & CVS-52/2/I & Faeces from egg layer hens \\
\hline Salmonella Enteritidis & CVS-54/I & Faeces from egg layer hens \\
\hline Salmonella Enteritidis & CVS-4792/I & Lymph ganglions \\
\hline Salmonella Enteritidis & CVS-4754/I & Lymph ganglions \\
\hline Salmonella Enteritidis & CVS-2553/4 & Skin from neck of chicken \\
\hline Salmonella Typhimurium & CVS-3225//I-5 & Sheftalia (pork sausage) \\
\hline Salmonella Typhimurium & CVS-4074/I & Parrot \\
\hline Salmonella Typhimurium & CVS-4076/I & Pigeon \\
\hline Salmonella Typhimurium & CVS-4255/I & Beef \\
\hline Salmonella Typhimurium & CVS-4345/4, 5 & Skin from neck of chicken \\
\hline Salmonella Typhimurium & CVS-4979/I & Dust from egg layer hen cages \\
\hline Salmonella Typhimurium & CVS-498I/I & Fish meal animal feed \\
\hline Salmonella Typhimurium & CVS-5090/I & Faeces from finches \\
\hline Salmonella Typhimurium & CVS-55/I & Faeces from egg layer hens \\
\hline Salmonella Typhimurium & CVS-920/1-3 & Egg yolk \\
\hline Salmonella Typhimurium & CVS-131/2 & Swab from swine \\
\hline Salmonella Typhimurium & CVS-729/2 & Swab from swine \\
\hline Salmonella Typhimurium & CVS-3794/I & Water \\
\hline Salmonella Typhimurium & CVS-3822/I & Water \\
\hline Salmonella Typhimurium & CVS- $1421 / 1$ & Lymph ganglions \\
\hline
\end{tabular}

${ }^{a}$ Identified by culture and serotyping methods as described in the Materials and Methods

late agar (XLD) and brilliant green agar (BGA) and incubated at $37^{\circ} \mathrm{C}$ for $24 \mathrm{~h}$. One colony was selected from each XLD and BGA plate and spread onto nutrient agar for incubation at $37^{\circ} \mathrm{C}$ for $24 \mathrm{~h}$. The resulting colonies were subject to biochemical analysis and serotyping. Salmonella spp. was characterised into different serovars on the basis of their surface (LPS, O-antigens) and flagellar antigens (H-antigens) as defined by the Kauffman-White Scheme $[10,44]$ and based on the Global Salm-Surv laboratory protocol of the World Health Organisation (Global SalmSurv, Serotyping of Salmonella enterica O and H antigen, Level 3 Training Course, WHO, $6^{\text {th }}$ edition, Jan. 2004).

To extract DNA for use in the molecular detection assay, bacteria were cultured on the XLD agar and one colony was selected and grown on nutrient agar. A colony was then selected and incubated in $5 \mathrm{ml}$ nutrient broth, $1 \mathrm{ml}$ of which was transferred into a $1.5 \mathrm{ml}$ tube for centrifugation for $10 \mathrm{~min}$ at $18,000 \mathrm{rcf}$. The supernatant was dis- carded and the cell pellet was kept at $-80^{\circ} \mathrm{C}$ until DNA extraction.

\section{Bacterial genomic DNA preparation}

Bacterial genomic DNA was extracted from the cell pellets using QIAGEN DNeasy Blood and Tissue Kit (Hilden, Germany) according to the manufacturer's instructions. The purified DNA was eluted in $100 \mu \mathrm{l}$ of AE buffer and the concentration was determined by measuring the optical density at $260 \mathrm{~nm}$ using a NanoDrop UV spectrophotometer (NanoDrop Technologies, USA). The extracted DNA was kept at $-30^{\circ} \mathrm{C}$ until further use.

\section{Internal amplification control}

An artificial 129 nt oligonucleotide fragment was designed as an IAC to be amplified by the same primers as the invA target. The IAC is a completely synthetic and unique oligonucleotide, designed to avoid sequence homology with any entries in the GenBank database, 
Table 2: Commercially Available Strains

\begin{tabular}{lc}
\hline Bacterial Strains & Reference ID \\
\hline Salmonella Typhimurium & $14028^{\mathrm{a}}$ \\
Salmonella Enteritidis & $13076^{\mathrm{a}}$ \\
Staphylococcus aureus & $1803^{\mathrm{b}}$ \\
Staphylococcus aureus & $25923^{\mathrm{a}}$ \\
Bacillus cereus & $7464^{\mathrm{b}}$ \\
Bacillus cereus & $11145^{\mathrm{b}}$ \\
Bacillus cereus & $11778^{\mathrm{a}}$ \\
Bacillus subtilis & $110649^{\mathrm{c}}$ \\
Enterobacter aerogenes & $13048^{\mathrm{a}}$ \\
Enterococcus faecalis & $29212^{\mathrm{a}}$ \\
Escherichia coli & $25922^{\mathrm{a}}$ \\
Escherichia coli OI57 & $35150^{\mathrm{a}}$ \\
Listeria innocua & $11288^{\mathrm{b}}$ \\
Listeria ivanovie & $11846^{\mathrm{b}}$ \\
Listeria ivanovie & $19119^{\mathrm{a}}$ \\
Listeria monocytogenes & $11994^{\mathrm{b}}$ \\
Micrococcus luteus & $9341^{\mathrm{a}}$ \\
Proteus vulgaris & $13315^{\mathrm{a}}$ \\
Pseudomonas aeruginosa & $27853^{\mathrm{a}}$ \\
Rhodococcus equi & $1621^{\mathrm{b}}$ \\
\hline
\end{tabular}

a Strains obtained from American Type Culture

Collection (ATCC), Manassas, USA http://www.atcc.org

b Strains obtained from National Collection of Type

Cultures (NCTC), London, UK http://www.nctc.org.uk

c Strains obtained from MERCK KGaA, Darmstadt, Germany http:// www.merck.de

tested using the BLAST (Basic Local Alignment Search Tool) software [45].

\section{Primer and beacon design}

All primers and molecular beacons described here were designed de novo for this study (See additional file 1: Oligonucleotide primers and molecular beacons in the realtime PCR assay). Small regions (133-136 nt) of the invA, prot $6 E$ and $f l i C$ genes were used as target sequences for the detection of Salmonella spp. S. Enteritidis and S. Typhimurium, respectively. The primers and the molecular beacons were designed based on sequences of the above genes found in the GenBank database http://

Table 3: Salmonella enterica serovars ${ }^{a}$

\begin{tabular}{lc}
\hline Serovar & Reference ID \\
\hline Salmonella Bredeney & $1030 / 1$ \\
Salmonella Infantis & $1030 / 4$ \\
Salmonella Anatum & $1030 / 5$ \\
Salmonella Hadar & $1030 / 6$ \\
Salmonella Newport & $1030 / 7$ \\
Salmonella Typhimurium & $1030 / 10$ \\
Salmonella Virchow & $1030 / 11$ \\
Salmonella Enteritidis & $1030 / 17$
\end{tabular}

a Obtained from the Community Reference Laboratory for Salmonella, RIVM, Bilthoven, the Netherlands http://www.rivm.nl
www.ncbi.nlm.nih.gov/Genbank/index.html using BLAST [45]. The molecular beacons, target oligonucleotides and primers were synthesised by MWG-Biotech AG Ltd (Ebersberg, Germany) and the Midland Certified Reagent Company, Incorporated (Texas, USA). For the stem formation, the ends of each beacon were designed to have a high GC content and to be complementary to each other. All beacons were labelled with DABCYL, i.e., 4 '-(4'dimethylaminophenylazo) benzoic acid at the 3 ' end and with one of four fluorophores at the $5^{\prime}$ end. Molecular beacon MBinvA, was labelled with the fluorophore FAM (Fluorescein); MBprot6E with TET (Tetrachloro-6'-carbofluorescein); MBfliC with HEX (hexachlorofluorescein); and MBIAC, with ROX (6'-carboxy-X-rhodamine). Within the loop element, each beacon contains a 22-25 nucleotide-long probe sequence complementary to the target. In addition to the probe sequence, each beacon has $4-5$ of the 12 bases of its two arms also complementary to the target. In this non-traditional way, once the beacon is in the open structure, it binds more forcefully to the target and the hybrid formed is more stable, and the maximum distance possible between fluorophore and quencher is created.

\section{Thermal denaturation characteristics of the molecular beacons}

To assess the thermodynamic characteristics, the quality and the purity of the molecular beacons used in this study, a melting curve analysis was performed on each using the 7900 HT Fast Real-Time PCR System (Applied Biosystems, Foster City, CA, USA). Briefly, the reaction consisted of a $25 \mu$ l solution containing $12.5 \mu$ l Platinum ${ }^{\circledast}$ PCR Supermix (Invitrogen), $1 \mu \mathrm{l}$ of the beacon probe at the appropriate concentration with or without $1 \mu \mathrm{l}(100 \mathrm{pmol})$ of a single-stranded oligonucleotide perfectly complementary to the probe. The cycling parameters were as follows: 1 cycle for 2 min at $95^{\circ} \mathrm{C}$ followed by 50 cycles, each consisting of the data collection step for $30 \mathrm{~s}$ and a second step for $10 \mathrm{~s}$, each starting at $80^{\circ} \mathrm{C}$ and employing autoincrementation of $-1{ }^{\circ} \mathrm{C}$ per half-minute cycle until $31^{\circ} \mathrm{C}$. Changes in fluorescence were measured at $490 \mathrm{~nm}$ and the data was collected at each temperature interval.

\section{PCR target standards synthesis, amplification and quantification}

PCR target standards of the fliC, invA, prot6E and IAC target sequences were synthesised by PCR amplification using long overlapping primers. Each PCR reaction was performed in a $50-\mu \mathrm{l}$ reaction volume containing $45 \mu \mathrm{l}$ of Platinum ${ }^{\circledast}$ PCR Supermix (Invitrogen, Inc., Carlsbad, CA, USA) and 25 pmoles each of the following primer pairs: for the fliC target, TFfliC and TRfliC; for the invA target, TFinvA and TRinvA; for the prot6E target, TFprot6E and TRprot6E; and for the IAC, TFIAC and TRIAC (See additional file 1: Oligonucleotide primers and molecular bea- 
cons in the real-time PCR assay). Amplification was performed with an activation step of $94^{\circ} \mathrm{C}$ for $30 \mathrm{~s}$, followed by 20 cycles, each consisting of $94^{\circ} \mathrm{C}$ for $20 \mathrm{~s}, 68^{\circ} \mathrm{C}$ for $30 \mathrm{~s}$ and $72^{\circ} \mathrm{C}$ for $20 \mathrm{~s}$, followed by a final extension step of $72^{\circ} \mathrm{C}$ for $5 \mathrm{~min}$ in an Eppendorf Mastercycler (Eppendorf AG, Hamburg, Germany). Three $\mu \mathrm{l}$ of the product from the first PCR was used in a secondary PCR in a $50-\mu$ l reaction volume containing $1 \times$ of Platinum $^{\otimes}$ PCR Supermix (Invitrogen, Inc., Carlsbad, CA) and 20 pmoles each of the following PCR primer pairs: for the fliC target, 585 and 717; for the invA target, 302 and 437; for the prot $6 \mathrm{E}$ target, 438 and 572; and for the IAC, 302 and 437 (See additional file 1: Oligonucleotide primers and molecular beacons in the real-time PCR assay). Amplification was performed with an activation step of $94^{\circ} \mathrm{C}$ for $30 \mathrm{~s}$, followed by 40 cycles, each consisting of $94^{\circ} \mathrm{C}$ for $20 \mathrm{~s}$, the annealing temperature for $30 \mathrm{~s}$ and $72^{\circ} \mathrm{C}$ for $20 \mathrm{~s}$, followed by a final extension step of $72^{\circ} \mathrm{C}$ for $5 \mathrm{~min}$ in an Eppendorf Mastercycler (Eppendorf AG, Hamburg, Germany). The annealing temperature for the fliC primers was $59^{\circ} \mathrm{C}$, for the invA primers $58^{\circ} \mathrm{C}$, for the prot $6 \mathrm{E}$ primers $56^{\circ} \mathrm{C}$ and for the IAC primers $58^{\circ} \mathrm{C}$. The resulting product was then cleaned using the QIAquick PCR Purification Kit (QIAGEN GmbH, Hilden, Germany) and eluted in $50 \mu \mathrm{l}$ of EB buffer. The PCR products were run on a $2 \%$ agarose gel with a 50 bp DNA ladder (Invitrogen) and the DNA concentration of each was measured on the NanoDrop ND-1000 UV Spectrophotometer (Wilmington, DE). The number of molecules per unit volume was calculated from the measured concentration and the molecular weight of each oligonucleotide. The amplified targets were then diluted to concentrations of $10^{6}$, $10^{5}, 10^{4}, 10^{3}, 10^{2}$ and 10 copies per $5 \mu \mathrm{l}$ to be used as target standards of known concentration.

\section{Standard curves}

Uniplex real-time PCR reactions were performed on 10fold serial dilutions of the PCR targets, synthesised and prepared as described above. Reactions of $25 \mu \mathrm{l}$ volume were set up, containing $12.5 \mu$ l Platinum ${ }^{\circledast}$ qPCR Supermix-UDG (Invitrogen, Carlsbad, CA), $1 \mu \mathrm{l}$ of forward primer and $1 \mu \mathrm{l}$ of reverse primer $(20 \mathrm{pmol} / \mu \mathrm{l}), 1 \mu \mathrm{l}$ of the corresponding molecular beacon at the concentration determined appropriate from the melting curve analysis (4.9 pmol $/ \mu \mathrm{l}$ MBinvA, $10 \mathrm{pmol} / \mu \mathrm{l} \mathrm{MBfliC}, 4.4 \mathrm{pmol} / \mu \mathrm{l}$ MBprot6E and $50 \mathrm{pmol} / \mu \mathrm{l} \mathrm{MBIAC}) 4.5 \mu \mathrm{H}_{2} \mathrm{O}$ and $5 \mu \mathrm{l}$ of the PCR target standard. The reactions were performed on the 7900 HT Real-Time PCR System (Applied Biosystems, Foster City, CA, USA) and the cycling parameters were as follows: activation step at $95^{\circ} \mathrm{C}$ for $10 \mathrm{~min}$, followed by 50 cycles, each consisting of $95^{\circ} \mathrm{C}$ for $15 \mathrm{~s}, 50^{\circ} \mathrm{C}$ for $30 \mathrm{~s}$ (data collection step) and $72^{\circ} \mathrm{C}$ for $30 \mathrm{~s}$.

\section{Uniplex real-time PCR}

The real-time PCR analysis was made with by the 7900 HT Fast Real-Time PCR System (Applied Biosystems) using the Platinum ${ }^{\circledast}$ Quantitative PCR SuperMix-UDG (Invitrogen) on all of the samples described above. Each $25 \mu \mathrm{l}$ uniplex PCR reaction contained $5 \mu$ l of the extracted DNA, and was carried out as described above. The fluorescence given out on hybridisation between each beacon and its target DNA was measured directly and the resulting amplification curves were processed immediately with the 7900 HT Sequence Detection Systems software v2.2.2 (Applied Biosystems, Foster City, CA). To verify that the fluorescence signals were due to PCR amplification of the template DNA and not any other contaminant, negative or non-template controls were also run, where sterile water replaced the DNA template in the reaction mixture.

\section{Double duplex real-time PCR}

Having tested all sets of beacons and primers in uniplex reactions, the samples were run again in a two-step duplex assay. In step 1, $25 \mu \mathrm{l}$ reactions were set up, containing $12.5 \mu \mathrm{l}$ of Platinum Quantitative Supermix-UDG (Invitrogen), $1 \mu \mathrm{l}$ of each of primers 302 and $437(20 \mathrm{pmol} / \mu \mathrm{l}), 1$ $\mu \mathrm{l}$ of MBIAC $(50 \mathrm{pmol} / \mu \mathrm{l}), 1 \mu \mathrm{l}$ of MBinvA $(4.9 \mathrm{pmol} / \mu \mathrm{l})$, $0.5 \mu \mathrm{l}$ of the synthetic IAC $\left(2 \times 10^{5}\right.$ copies $\left./ \mu \mathrm{l}\right)$. To this, 2 $\mu \mathrm{l}$ of 100 -fold dilution of sample DNA were added and the volume was made up with sterile water or, in the case of non-template controls, the sample DNA was replaced with sterile water. In step 2, each reaction had a total volume of $25 \mu \mathrm{l}$ consisting of $12.5 \mu \mathrm{l}$ of Platinum Quantitative Supermix-UDG (Invitrogen), $1 \mu$ l of each of 572,585 and $717(20 \mathrm{pmol} / \mu \mathrm{l}), 1 \mu \mathrm{l}$ of MBprot6E $(4.4 \mathrm{pmol} / \mu \mathrm{l})$ and $2 \mu \mathrm{l}$ of MBfliC $(10 \mathrm{pmol} / \mu \mathrm{l})$. The final volume was reached by the addition of $2 \mu \mathrm{l}$ of sample DNA and $3.5 \mu \mathrm{l}$ of sterile water or, in the case of non-template negative control reactions, $5.5 \mu \mathrm{l}$ of sterile water only. For both steps, PCR cycling conditions were as described for the standard curve analysis and uniplex reactions. The fluorescence given out on hybridisation between beacon and its target was measured at each cycle.

\section{Results}

\section{Thermal denaturation characteristics of molecular} beacons

Normalised fluorescence signals for both the beacon and the beacon-target hybrid were plotted against temperature to give a thermal denaturation profile for each beacon (Fig. 1). These profiles were created using an ABI 7900 HT Fast Real-Time PCR System (Applied Biosystems, Foster City, CA) to determine the optimal hybridisation temperature between the beacon and its target sequence. Perfectly complementary beacon-target hybrids exist at lower temperatures giving out a bright fluorescence signal. A progressive increase in temperature causes the hybrids to dissociate, followed by a marked decrease in fluorescence. Conversely, the beacons alone unravelled at high temperatures and exhibited a melting temperature above $60^{\circ} \mathrm{C}$ in all cases. In the temperature interval from 31 to $55^{\circ} \mathrm{C}$, the probe-target hybrids elicited significantly stronger fluores- 
cence than the probe alone, thus allowing the detection of target sequence at these temperatures. A temperature of $50^{\circ} \mathrm{C}$ was chosen as an optimal annealing temperature for subsequent real-time PCR studies. At this temperature the difference in fluorescence signal between beacon alone and beacon-target hybrids is large; in the absence of target any fluorescence detected is background level and the temperature is high enough to prevent less energetically favourable hybrids from forming, e.g., primer dimers or beacon-primer dimers. In the process of carrying out the melting curve analysis for all beacons, different concentrations were tested, to find the appropriate concentration at which the fluorescence signal was neither too low nor saturated. The concentrations at which the particular beacons exhibited the desired amount of fluorescence signal in these reactions were: MBIAC, $50 \mathrm{pmol} / \mu \mathrm{l} ; \mathrm{MBinvA}, 4.9$ $\mathrm{pmol} / \mu \mathrm{l} ; \mathrm{MBprot} 6 \mathrm{E}, 4.4 \mathrm{pmol} / \mu \mathrm{l}$; and MBfliC, $10 \mathrm{pmol} /$ $\mu \mathrm{l}$. Finally, these thermal denaturation profiles illustrate

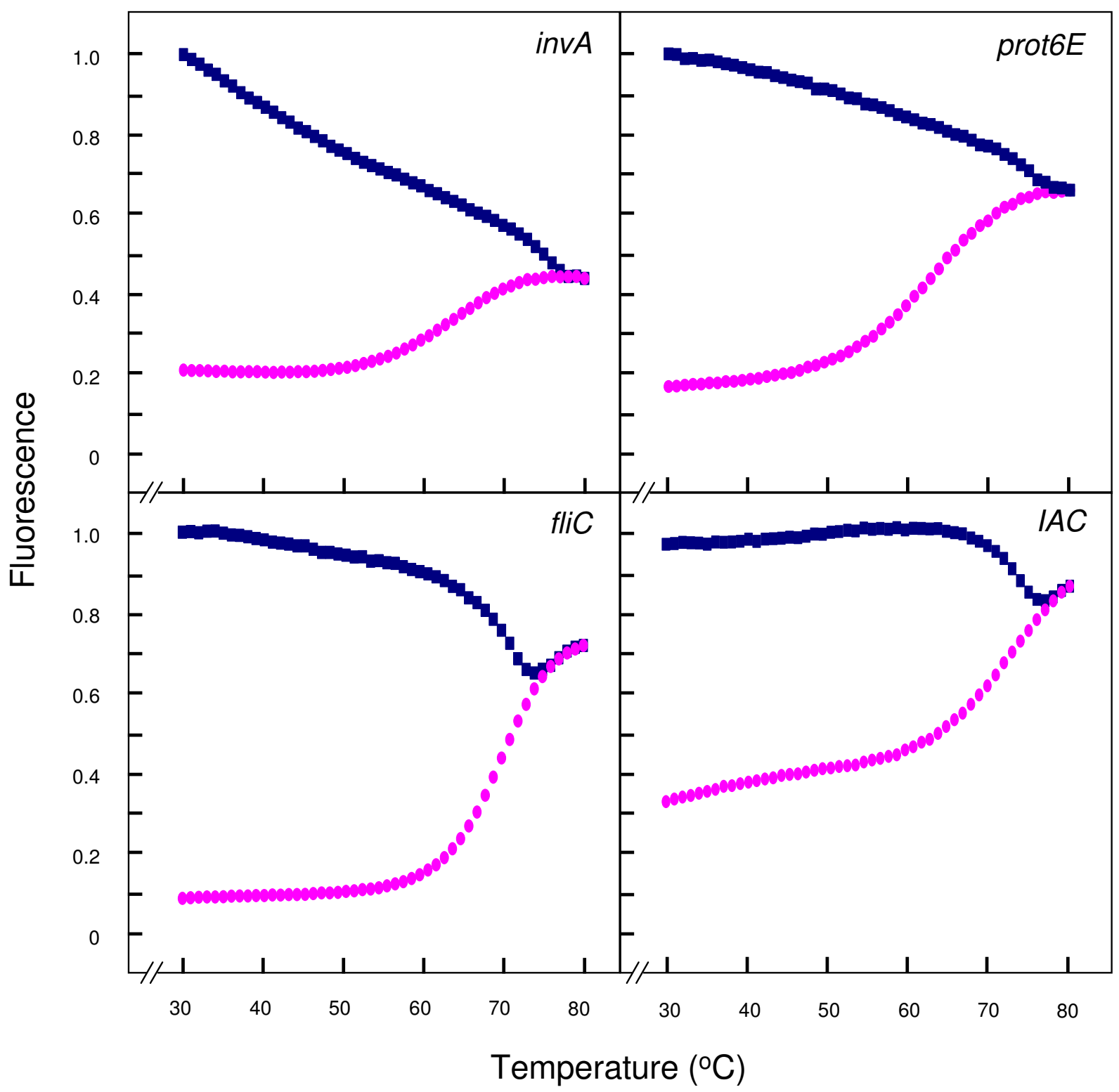

Figure I

Thermal denaturation profiles of the molecular beacons. Thermal denaturation profiles of the molecular beacons used in this study as established by melting curve analysis (described in Materials and Methods). The figure shows normalised fluoresence thermal transitions of molecular beacon plotted in pink circles and beacon-target complexes plotted in blue squares. 
the good quality of the molecular beacons and their efficiency in hybridising with the appropriate target sequence.

\section{Standard curves and limit of detection}

Standard curves were initially plotted to ensure the ability of each molecular beacon to detect its specific Salmonella target and the detection limit of the assay. The copy numbers of target standards used ranged from $10^{1}$ to $10^{6}$ copies per reaction. These plots represent how the amplification of DNA progresses with each log increase of target copy number. The small standard errors calculated from multiple values of the threshold cycle at which significant DNA amplification was observed (threshold cycle, $\mathrm{C}_{\mathrm{T}}$ ) for each reaction and indicated on the graphs with horizontal lines above and below each plotted point, suggest that the PCR amplification is highly reproducible. The $\mathrm{C}_{\mathrm{T}}$ values for the target sequences depended on the initial DNA amount in each reaction as shown by the linear relationship of standard curves along a 6-log range which yields an $\mathrm{R}^{2}$ correlation value higher than 0.994 in all three cases (Fig. 2). The correlation was 0.995 with $76 \%$ efficiency for invA, 0.997 and $84 \%$ efficiency for prot6E and 0.999 and $100 \%$ efficiency for fliC. As the reactions worked well for all target standard concentrations tested, the lower limit of detection for the assay was set to be 10 copies of the required target fragment per reaction. Based on the standard curves and the limit of detection of this assay, negative results were defined as those exhibiting $C_{T}$ values higher than 45 .

\section{Detection of S. enterica alleles in bacterial samples by molecular beacon-based uniplex real-time PCR}

The molecular beacon-based real-time PCR assay designed in this study was tested on environmental and food samples of $S$. Enteritidis and $S$. Typhimurium (Table $1)$, as well as several commercially available bacterial strains (Table 2) and various Salmonella serovars obtained from a reference laboratory for Salmonella (Table 3). All samples were investigated first by uniplex assays to detect invA, prot6E and fliC (Table 4). In the reaction for detection of invA, all 44 Salmonella samples were positive and all 18 non-Salmonella samples were undetectable. Positive results ( $\leq 10$ copies of DNA per reaction) had $\mathrm{C}_{\mathrm{T}}$ values ranging from 15 to 25 . In the prot6E reaction, all $21 S$. Enteritidis samples gave positive PCR results and all 41 non-Enteritidis samples were negative. Positive samples for the prot $6 E$ gene had $\mathrm{C}_{\mathrm{T}}$ values ranging between 15 and 18 with one exception, the commercially available specimen of $S$. Enteritidis (Table 3) for which fluorescence detection significantly increased around cycle 30. Finally, in the fliC reaction, all $17 \mathrm{~S}$. Typhimurium samples gave positive PCR results and all 45 non-Typhimurium samples were negative. Positive results had $\mathrm{C}_{\mathrm{T}}$ values ranging from 15 to 18 cycles. These results showed that the primers and beacons for each reaction work well individually and that they amplify and detect their target sequence with very high specificity and sensitivity. The $\mathrm{C}_{\mathrm{T}}$ values exhibited by the samples in these experiments, compared to the plot of the standards of known concentration, indicated that the extracted DNA from the bacterial samples

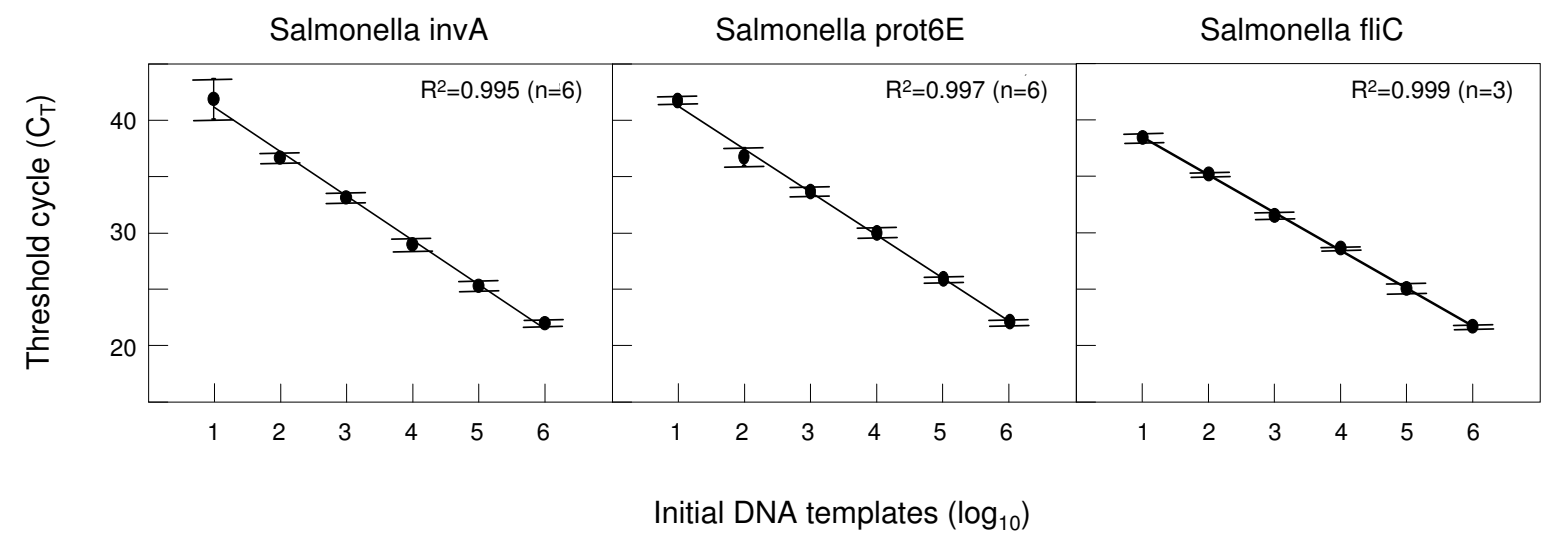

\section{Figure 2}

Standard curves for targets invA, fliC and prot6E. Standard curves for molecular beacon-based real-time PCR detection of targets invA, fliC and prot6E. The plots illustrate the relationship of known number of target DNA copies per reaction to the threshold cycle of detection $\left(C_{T}\right)$ for each molecular beacon reaction. The $C_{T}$ is directly proportional to the log of the input copy equivalents, as demonstrated by the standard curves generated. 
Table 4: Real-time PCR results obtained using the available bacterial strains

\begin{tabular}{|c|c|c|c|c|c|}
\hline \multirow[b]{2}{*}{ Bacterial strain ${ }^{a}$} & \multirow[b]{2}{*}{ Reference ID } & \multicolumn{4}{|c|}{ PCR Result ${ }^{b}$} \\
\hline & & $\mathrm{IAC}$ & $\operatorname{invA}$ & prot6E & flic \\
\hline Salmonella Enteritidis & CVS-140/I & & + & + & - \\
\hline Salmonella Enteritidis & CVS-I4I/I-5 & & + & + & - \\
\hline Salmonella Enteritidis & CVS-4054/I & & + & + & - \\
\hline Salmonella Enteritidis & CVS-43II/I & & + & + & - \\
\hline Salmonella Enteritidis & CVS-4325/4, 5 & & + & + & - \\
\hline Salmonella Enteritidis & CVS-442I/I & & + & + & - \\
\hline Salmonella Enteritidis & CVS-45I6/I & & + & + & - \\
\hline Salmonella Enteritidis & CVS-4532/I & & + & + & - \\
\hline Salmonella Enteritidis & CVS-4540/I & & + & + & - \\
\hline Salmonella Enteritidis & CVS-4666/I & & + & + & - \\
\hline Salmonella Enteritidis & CVS-4756/I & & + & + & - \\
\hline Salmonella Enteritidis & CVS-4807//I-3 & & + & + & - \\
\hline Salmonella Enteritidis & CVS-4809/2 & & + & + & - \\
\hline Salmonella Enteritidis & CVS-4980/I & & + & + & - \\
\hline Salmonella Enteritidis & CVS-5212/I & & + & + & - \\
\hline Salmonella Enteritidis & CVS-54/I & & + & + & - \\
\hline Salmonella Enteritidis & CVS-4792/I & & + & + & - \\
\hline Salmonella Enteritidis & CVS-4754/I & & + & + & - \\
\hline Salmonella Enteritidis & CVS-2553/4 & & + & + & - \\
\hline Salmonella Typhimurium & CVS-3225//I-5 & & + & - & + \\
\hline Salmonella Typhimurium & CVS-4074/I & & + & - & + \\
\hline Salmonella Typhimurium & CVS-4076/I & & + & - & + \\
\hline Salmonella Typhimurium & CVS-4255/I & & + & - & + \\
\hline Salmonella Typhimurium & CVS-4345/4, 5 & & + & - & + \\
\hline Salmonella Typhimurium & CVS-4979/I & & + & - & + \\
\hline Salmonella Typhimurium & CVS-4981/I & & + & - & + \\
\hline Salmonella Typhimurium & CVS-5090/I & & + & - & + \\
\hline Salmonella Typhimurium & CVS-55/I & & + & - & + \\
\hline Salmonella Typhimurium & CVS-920/1-3 & & + & - & + \\
\hline Salmonella Typhimurium & CVS-131/2 & & + & - & + \\
\hline Salmonella Typhimurium & CVS-729/2 & & + & - & + \\
\hline Salmonella Typhimurium & CVS-3794/I & & + & - & + \\
\hline Salmonella Typhimurium & CVS-3822/I & & + & - & + \\
\hline Salmonella Typhimurium & CVS-I42I/I & & + & - & + \\
\hline Salmonella Typhimurium & 14028 & & + & - & + \\
\hline Salmonella Enteritidis & 13076 & & + & + & - \\
\hline Staphylococcus aureus & 1803 & & - & - & - \\
\hline Staphylococcus aureus & 25923 & & - & - & - \\
\hline Bacillus cereus & 7464 & & - & - & - \\
\hline Bacillus cereus & 11145 & & - & - & - \\
\hline Bacillus cereus & 11778 & & - & - & - \\
\hline Bacillus subtilis & 110649 & & - & - & - \\
\hline Enterobacter aerogenes & 13048 & & - & - & - \\
\hline Enterococcus faecalis & 29212 & & - & - & - \\
\hline Escherichia coli & 25922 & & - & - & - \\
\hline Escherichia coli OI57 & 35150 & & - & - & - \\
\hline Listeria innocua & 11288 & & - & - & - \\
\hline Listeria ivanovie & 11846 & & - & - & - \\
\hline Listeria ivanovie & 19119 & & - & - & - \\
\hline Listeria monocytogenes & I 1994 & & - & - & - \\
\hline Micrococcus luteus & 9341 & & - & - & - \\
\hline Proteus vulgaris & 13315 & & - & - & - \\
\hline Pseudomonas aeruginosa & 27853 & & - & - & - \\
\hline Rhodococcus equi & 1621 & & - & - & - \\
\hline Salmonella Bredeney & $1030 / 1$ & & + & - & - \\
\hline Salmonella Infantis & $1030 / 4$ & & + & - & - \\
\hline
\end{tabular}

was higher than the range of concentrations tested by the standards ( $>10^{7}$ copies per reaction). Therefore 100-fold dilutions of all extracted DNA samples were prepared for use in the two-step duplex assay, so that the resulting $\mathrm{C}_{\mathrm{T}}$ values would fall within the range seen on the standard curves.

\section{Detection of S. enterica alleles in bacterial samples by molecular beacon-based two-step duplex real-time PCR}

All samples were subsequently tested employing a double duplex strategy, where the first step of the assay involved a real-time PCR reaction containing the primers and beacons for the amplification and detection of both the invA gene and the IAC, a quantity of which was inserted into each reaction. This step of the assay determined the presence or absence of the invA gene to verify whether the sample was Salmonella or not. Simultaneous amplification and detection of the IAC in all samples ensured accurate PCR performance, therefore excluding the possibility of false-negative results. Amplification and detection of both invA and the IAC were clear in all Salmonella samples, whereas only the IAC amplification was detected in nonSalmonella samples. Representative amplification plots from Salmonella and other bacteria for the first step reaction are seen in Fig. 3. The results demonstrate that this reaction correctly recognises samples in which Salmonella exist from samples in which it does not.

All samples found positive for invA in the first step were then tested in the second step of the assay, another duplex real-time PCR reaction containing the components for amplification and detection of both prot $6 \mathrm{E}$ and fliC targets. In all $S$. Typhimurium samples $f l i C$ was the only target detected, in all $S$. Enteritidis samples prot6E was the only target detected and in all other Salmonella samples, both targets were undetected. The results show that this reaction clearly and accurately distinguishes between $S$. Typhimurium strains, $S$. Enteritidis strains and other Salmonella serotypes. Representative amplification plots from $S$. Typhimurium, $S$. Enteritidis and other Salmonellae for the second step reaction are seen in Fig. 4, clearly showing that the prot6E and fliC components designed in this study work well together in a multiplex real-time PCR reaction.

In both the uniplex and double duplex assays, non-template controls were included to verify the absence of falsepositive results. In all cases they exhibited undetectable amplification of the targets $\left(\mathrm{C}_{\mathrm{T}}>45\right)$.

\section{Selectivity of the real-time assay}

The selectivity and accuracy of the test is measured by calculating the values for specificity and sensitivity. Specificity is the probability that the PCR will be negative among specimens that should not possess the gene and is calcu- 
Table 4: Real-time PCR results obtained using the available bacterial strains (Continued)

\begin{tabular}{lllll}
\hline Salmonella Anatum & $1030 / 5$ & + & - & - \\
Salmonella Hadar & $1030 / 6$ & + & - & - \\
Salmonella Newport & $1030 / 7$ & + & - & - \\
Salmonella Typhimurium & $1030 / 10$ & + & - & + \\
Salmonella Virchow & $1030 / 11$ & + & - & - \\
Salmonella Enteritidis & $1030 / 17$ & + & + & -
\end{tabular}

a The origin of these samples has been described in tables I, 2 and 3 . ${ }^{b}$ Detectable real-time PCR amplification signal is denoted by the symbol $(+)$ which indicates $C_{T}$ values $\leq 45$. Undetectable signal $\left(C_{T}\right.$ values $>45)$ is denoted by $(-)$ and indicates the absence of template DNA.

cIAC is an artificial internal amplification control that does not correspond to any of the submitted sequences in the Genbank.

lated using the formula: true negative/(true negative + false positive). Sensitivity shows the strength of the test in recognising what we are looking for, i.e., in correctly identifying the specific serotype. The formula used for estimation of sensitivity is: true positive/(true positive + false negative). For the reaction targeting the invA gene, all 44 Salmonella samples investigated were positive indicating a sensitivity of $100 \%$. The specificity was also $100 \%$ since all non-Salmonella samples gave negative results, with undetectable fluorescence signals after 50 cycles. In the prot6E reaction all $S$. Enteritidis samples analysed were identified correctly with positive PCR results and all nonEnteritidis samples were negative for this target. Thus, this reaction also had sensitivity and specificity of 100\%. Similarly, in the assay for fliC detection, all S. Typhimurium samples tested were positive for the target. The assay's sensitivity was $100 \%$, matched by an equal specificity value as all non-Typhimurium samples tested gave negative PCR results.

\section{Discussion}

Traditional serotyping of S. enterica is based on the detection of certain antigens using microbiological techniques and culturing, which are time-consuming and laborious. This study exploits real-time PCR, molecular beacons and genetic variation between different serotypes to devise a quick, accurate and simple assay to reliably identify a bacterial sample as Salmonella enterica and further distinguish it as serotypes $S$. Typhimurium or $S$. Enteritidis, the two serovars most commonly associated with food-borne gastroenteritis. The assay described in this study can analyse a large number of samples very quickly, and can also identify as few as 10 copies of target DNA per reaction, potentially even in the presence of thousands of copies of other serotypes. The short completion time of this assay and the ability of PCR to detect even dead bacterial cells, even though these are no longer infectious, highlight the drawbacks of the culturing method and the need to start using modern molecular techniques as opposed to conventional microbiology methods where applicable. PCR sensitivity is superior to that of the bacteriological culturing methods, as it can detect Salmonellas with atypical biochemical features, reducing false-negative results, and it will not mistakenly detect non-Salmonella bacteria, reducing the chances of false-positive data [27]. However, further research is necessary to ensure that molecular assays alone can efficiently detect Salmonella spp. and its serotypes.

A variety of bacterial samples were used to test the specificity of the assay in the detection of the genus Salmonella. At the same time a number of Salmonella strains were included to ensure that the detection tests for serovars $S$. Typhimurium and $S$. Enteritidis were specific. The study includes strains from clinical and environmental samples as well as commercially available strains, and a significant number of $S$. Typhimurium and $S$. Enteritidis samples as well as other Salmonella serotypes and non-Salmonella bacteria. This broad range of samples was included to test the efficacy of the assay. Three genes were specifically targeted: the invA gene specific to the genus Salmonella; the prot6E gene specific to $S$. Enteritidis; and the fliC gene specific to $S$. Typhimurium. Due to its specificity, the invA gene is an excellent potential target for the detection of $S$. enterica strains alone $[18,24,28,30-43]$. The fact that it is unique for $S$. enterica and rarely absent from it [46], ensures high specificity and sensitivity in detection assays. The prot6E gene is located on a highly conserved, low copy number, $60-\mathrm{kb}$ virulence plasmid specific to $S$. Enteritidis and its absence appears to be very rare [18]. Finally, the fliC gene codes for the $\mathrm{H} 1$ antigen of Salmonella. Targeting the fliC- $i$ allele greatly increases the specificity for $S$. Typhimurium identification. In order to detect $S$. Typhimurium with the highest specificity, three genes could ideally be targeted, coding for antigens $\mathrm{O}: 4, \mathrm{H} 1: \mathrm{i}$ and $\mathrm{H} 2: 1,2$, as it is the only serovar with this antigen combination [47]. However, this would not only raise the costs of the assay but would compromise the simplicity of design and the potential for including further molecular beacons in the multiplex reaction for identification of other target serotypes. Thus, in this study, as in some other studies $[48,49]$, the fliC gene has been chosen as a single target for the presence of $S$. Typhimurium. By designing the fliC beacon using a $S$. Typhimurium sequence from the GenBank database as a template, the assay exhibits high sensitivity. However, although it performed with $100 \%$ specificity with this particular set of samples, in a different set of samples, e.g., with other $S$. enterica serotypes like Kentucky that also possess the $\mathrm{H} 1$ :i antigen, it might yield different results. Many different genes have been targeted in previous studies $[16,22,25,26,30,47,48,50-54]$. However, the above targets did not prove to be specific enough for unique detection and identification.

The IAC used is a synthetic and unique oligonucleotide designed de novo for this study. The fact that this IAC is co- 
Salmonella

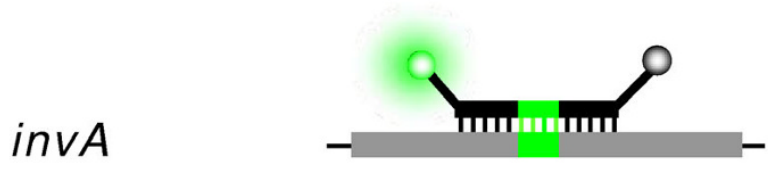

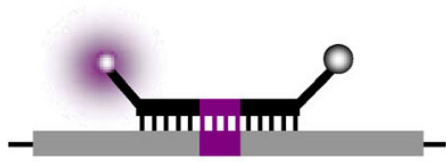

\section{Other bacteria}
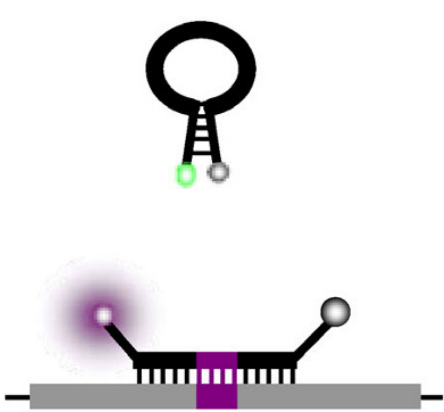

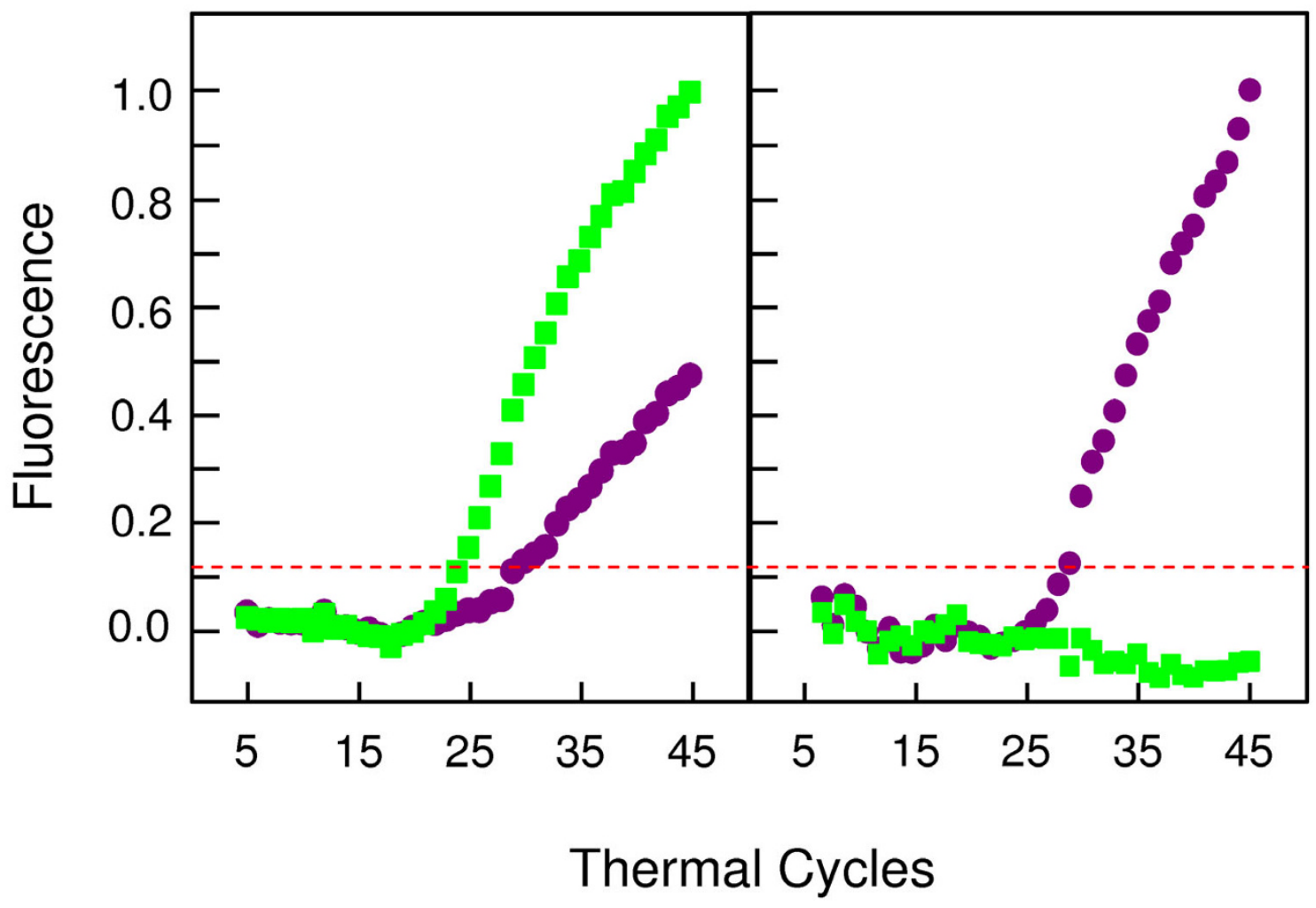

Figure 3

Schematic real-time PCR results for the first step reaction. Representative real-time PCR results as established by the first step multiplex reaction (described in Materials and Methods). The plots show average normalised linear amplification of representative samples shown for demonstration of typical results obtained from Salmonella and non-Salmonella bacteria. With DNA from non-Salmonella bacterial samples, only the IAC-specific, ROX-labelled molecular beacons hybridise to the IAC amplicons, generating violet fluorescence, whereas the invA-specific, FAM-labelled molecular beacons retain their stem-andloop structure and cannot produce a green fluorescent signal. With DNA from Salmonella samples, both molecular beacons hybridise to their respective target amplicons and generate both green and violet fluorescence. The dashed line on the plots represents the normalised threshold for detection of fluorescence, the baseline above which fluorescence increases significantly on amplification and detection of the target sequence. 


\section{Other Salmonella}

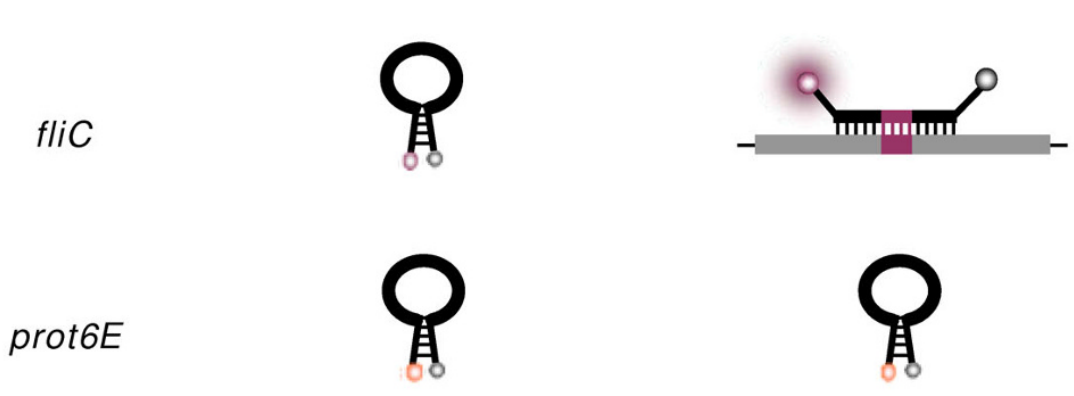

S. Typhimurium

\section{S. Enteritidis}
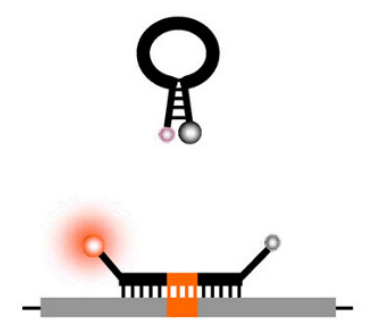

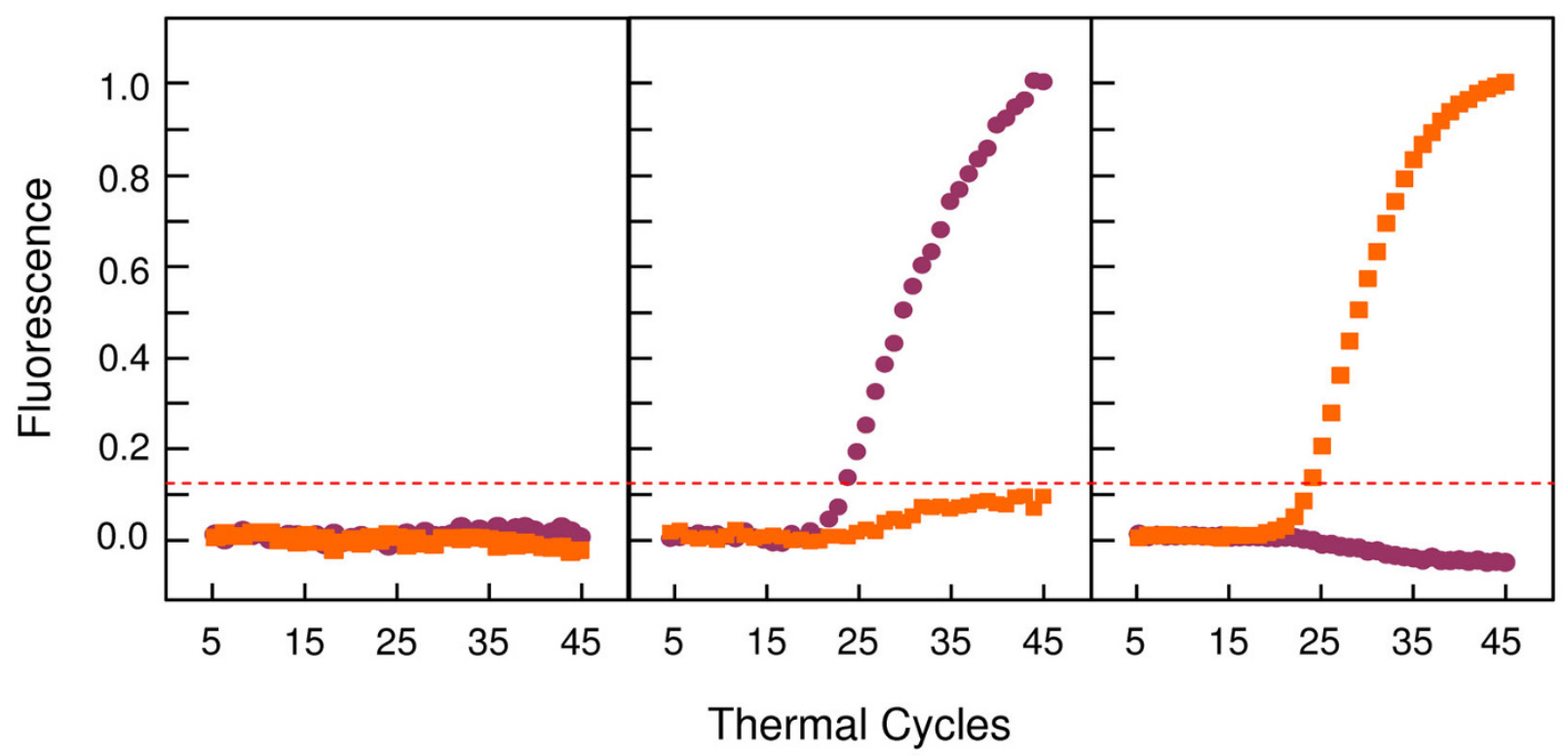

Figure 4

Schematic real-time PCR results for the second step reaction. Representative real-time PCR results as established by the second step multiplex reaction (described in Materials and Methods). The plots show average normalised linear amplification of representative samples shown for demonstration of typical results obtained from $\mathrm{S}$. Typhimurium, $\mathrm{S}$. Enteritidis and other Salmonella samples. With DNA from S. Typhimurium strains, only fliC-specific, HEX-labelled molecular beacons hybridise to the amplicons, generating pink fluorescence, whereas the prot6E-specific, TET-labelled molecular beacons retain their stemand-loop structure and cannot produce an orange fluorescent signal. With DNA from S. Enteritidis strains, the prot6E-specific, TET-labelled molecular beacons hybridise to their target amplicons and produce an orange fluorescent signal, whereas the fliCspecific, HEX-labelled molecular beacons remain dark. With DNA from other Salmonella serotypes, no target amplicons are detected and both molecular beacons remain dark. The dashed line on the plots represents the normalised threshold for detection of fluorescence, the baseline above which fluorescence increases significantly on amplification and detection of the target sequence.

amplified with the invA fragment using the same primer set but detected by a distinct beacon, does not appear to alter the precision and accuracy of the real-time PCR, and quantification of original target DNA is still possible even in the presence of the control. However, the standard curve protocol for invA in the presence of the IAC should be performed for a correct quantitative approach if the assay is to be used for quantification. The invA gene has been used as an internal amplification control in other studies [18], but its application is limited to Salmonella assays alone. Furthermore, it has been found that in some rare cases, this gene may be absent and is therefore unreliable as an amplification control even for studies incorporating Salmonella specimens alone. This IAC sequence matches no organism in the NCBI libraries and could potentially be used in any such detection assays. 
The assays for the invA, fliC and prot6E genes all had a sensitivity and specificity score of $100 \%$. All 45 Salmonella samples were positive, with $100 \%$ sensitivity. Positive results ( $>10$ copies of DNA per reaction) had $C_{T}$ values ranging from 15 to 25 . One exception, the commercially available specimen of $S$. Enteritidis (Table 3), had a $C_{T}$ value of approximately 30 . Since the prot $6 E$ gene is located on a virulence plasmid, its absence would not be surprising. Plasmid profiling should be performed to explain the unusually high $\mathrm{C}_{\mathrm{T}}$ value observed for this specific specimen. This raises the question of whether selecting a target on a plasmid is a wise choice, but this absence of this plasmid has been found to be rare from $S$. Enteritidis and the low copy numbers (1-2) of the plasmid in the cells make possible the conversion of the assay to a quantitative one which would be correct to a factor of 2 . Therefore, using this target for quantification would depend on the accuracy required.

Our study is the first to incorporate four molecular beacons with real-time PCR in a double duplex PCR protocol to detect Salmonella spp., Salmonella Enteritidis and Salmonella Typhimurium in a single assay. Strong fluorescence signals were observed in all positive PCR results in both the uniplex and the duplex assays, indicating the efficiency of the design in the primers and beacons. The sensitivity and specificity of the design and procedure described here give the assay the potential to be converted into a quantitative method, directly applied to samples without the requirement of pre-enrichment stages, making use of the standard curves.

\section{Conclusion}

This molecular beacon-based real-time PCR assay is extremely useful for any laboratory in possession of a realtime PCR. It is a fast, reproducible, simple, specific and sensitive way to detect nucleic acids, which could be used in clinical diagnostic tests in the future. The design of the assay gives it potential to be used for quantification, for detection of multiple other serotypes of Salmonella or to be modified for the detection of other bacterial samples. Also, more significantly, the sensitivity of the test and its confirmed low limit of detection, are promising factors for the important switch to direct detection from real clinical and environmental samples which have not been previously cultured and have low numbers of bacteria.

\section{Authors' contributions}

AVH participated in the assay design, sample preparation, real-time PCR experimental procedures, the analysis and interpretation of the results and drafted the manuscript. VLD carried out sample preparation, real-time experimental procedures, analysis and interpretation of results and drafted the manuscript. MAE carried out the bacterial culturing and serotyping techniques, sample selection, bacte- rial pellets isolation and helped with the manuscript preparation. CKK participated in sample selection and donated samples for this study. LGK conceived and designed the assay, coordinated the study and participated in sample selection and analysis and interpretation of results. All authors read and approved the final manuscript.

\section{Additional material}

\section{Additional File 1}

Oligonucleotide primers and molecular beacons in the real-time PCR assay. Table of primer and molecular beacon sequences used in this study. Click here for file

[http://www.biomedcentral.com/content/supplementary/14712180-9-97-S1.doc]

\section{Acknowledgements}

The authors would like to thank the staff at the Department of Veterinary Services, Nicosia for assisting in sample collection; S. Gilliland and J. Hezka for technical assistance.

This work was supported by research funds from the University of Cyprus (awarded to L. G. Kostrikis) and the Birch Biomedical Research LLC.

\section{References}

I. Gorman R, Adley CC: Characterization of Salmonella enterica serotype Typhimurium isolates from human, food, and animal sources in the Republic of Ireland. J Clin Microbiol 2004, 42(5):23|4-23|6.

2. Tindall BJ, Grimont PA, Garrity GM, Euzeby JP: Nomenclature and taxonomy of the genus Salmonella. Int J Syst Evol Microbiol 2005, 55(Pt I):52I-524.

3. Brenner FW, Villar RG, Angulo FJ, Tauxe R, Swaminathan B: Salmonella nomenclature. J Clin Microbiol 2000, 38(7):2465-2467.

4. Baylis CL, MacPhee S, Betts RP: Comparison of methods for the recovery and detection of low levels of injured Salmonella in ice cream and milk powder. Lett Appl Microbiol 2000, 30(4):320-324.

5. Baylis CL, MacPhee S, Betts RP: Comparison of two commercial preparations of buffered peptone water for the recovery and growth of Salmonella bacteria from foods. J Appl Microbiol 2000, 89(3):50I-5I0.

6. Hoorfar J, Baggesen DL: Importance of pre-enrichment media for isolation of Salmonella spp. from swine and poultry. FEMS Microbiol Lett 1998, 169(I): 125-130.

7. Uyttendaele M, Vanwildemeersch K, Debevere J: Evaluation of real-time PCR vs automated ELISA and a conventional culture method using a semi-solid medium for detection of Salmonella. Lett Appl Microbiol 2003, 37(5):386-39I.

8. Voogt N, Raes M, Wannet WJ, Henken AM, Giessen AW van de: Comparison of selective enrichment media for the detection of Salmonella in poultry faeces. Lett Appl Microbiol 200I, 32(2):89-92.

9. Popoff MY, Le Minor L: Antigenic formulas of the Salmonella serovars, 7th revision. Institut Pasteur, Paris; 1997.

10. Popoff MY, Bockemuhl J, Gheesling LL: Supplement 2002 (no. 46) to the Kauffmann-White scheme. Res Microbiol 2004, I55(7):568-570.

II. Yoshida C, Franklin K, Konczy P, McQuiston JR, Fields PI, Nash JH, Taboada EN, Rahn K: Methodologies towards the development of an oligonucleotide microarray for determination of Salmonella serotypes. J Microbiol Methods 2007, 70(2):26I-27I. 
I2. Hoorfar J, Mortensen AV: Improved culture methods for isolation of Salmonella organisms from swine feces. Am J Vet Res 2000, 6 I (I I): | 426-I429.

13. Marras SA, Kramer FR, Tyagi S: Multiplex detection of singlenucleotide variations using molecular beacons. Genet Ana 1999, |4(5-6): | $5|-| 56$.

14. Marras SA, Tyagi S, Kramer FR: Real-time assays with molecular beacons and other fluorescent nucleic acid hybridization probes. Clin Chim Acta 2006, 363(I-2):48-60.

15. Tyagi S, Kramer FR: Molecular beacons: probes that fluoresce upon hybridization. Nat Biotechnol 1996, I 4(3):303-308.

16. Ellingson JL, Anderson JL, Carlson SA, Sharma VK: Twelve hour real-time PCR technique for the sensitive and specific detection of Salmonella in raw and ready-to-eat meat products. Mol Cell Probes 2004, I 8(I):5 I-57.

17. Josefsen $M H$, Krause M, Hansen F, Hoorfar J: Optimization of a I 2Hour TaqMan PCR-Based Method for Detection of Salmonella Bacteria in Meat. Appl Environ Microbiol 2007 73(9):3040-3048.

18. Malorny B, Bunge C, Helmuth R: A real-time PCR for the detection of Salmonella Enteritidis in poultry meat and consumption eggs. J Microbiol Methods 2007, 70:245-25I

19. Malorny B, Made D, Teufel P, Berghof-Jager C, Huber I, Anderson A Helmuth R: Multicenter validation study of two blockcyclerand one capillary-based real-time PCR methods for the detection of Salmonella in milk powder. Int J Food Microbiol 2007, | | 7(2):2 | |-2 | 8

20. Malorny B, Paccassoni E, Fach P, Bunge C, Martin A, Helmuth R Diagnostic real-time PCR for detection of Salmonella in food. Appl Environ Microbiol 2004, 70( I 2):7046-7052.

21. Massi MN, Shirakawa T, Gotoh A, Bishnu A, Hatta M, Kawabata M Quantitative detection of Salmonella enterica serovar Typhi from blood of suspected typhoid fever patients by real-time PCR. Int I Med Microbiol 2005, 295(2): I I 7-I 20.

22. Moore MM, Feist MD: Real-time PCR method for Salmonella spp. targeting the stn gene. I Appl Microbiol 2007 I 02(2):5 | 6-530.

23. Reynisson $E$, Josefsen $M H$, Krause M, Hoorfar J: Evaluation of probe chemistries and platforms to improve the detection limit of real-time PCR. J Microbiol Methods 2006, 66(2):206-2I6.

24. Shannon KE, Lee DY, Trevors JT, Beaudette LA: Application of real-time quantitative $P C R$ for the detection of selected bacterial pathogens during municipal wastewater treatment. Sci Total Environ 2007, 382(I): I 21 - I 29

25. Chen W, Martinez G, Mulchandani A: Molecular beacons: a realtime polymerase chain reaction assay for detecting Salmonella. Anal Biochem 2000, 280(I): I66-172

26. Liming SH, Bhagwat AA: Application of a molecular beaconreal-time PCR technology to detect Salmonella species contaminating fruits and vegetables. Int I Food Microbiol 2004 95(2): I77- I87.

27. Patel JR, Bhagwat AA, Sanglay GC, Solomon MB: Rapid detection of Salmonella from hydrodynamic pressure-treated poultry using molecular beacon real-time PCR. Food Microbiol 2006 23(I):39-46

28. Daum LT, Barnes WJ, McAvin JC, Neidert MS, Cooper LA, Huff WB, Gaul L, Riggins WS, Morris S, Salmen A, et al: Real-time PCR detection of salmonella in suspect foods from a gastroenteritis outbreak in kerr county, Texas. J Clin Microbiol 2002 40(8):3050-3052.

29. Rahn K, De Grandis SA, Clarke RC, McEwen SA, Galan JE, Ginocchio C, Curtiss R 3rd, Gyles CL: Amplification of an invA gene sequence of Salmonella typhimurium by polymerase chain reaction as a specific method of detection of Salmonella. Mol Cell Probes 1992, 6(4):27I-279.

30. Cortez AL, Carvalho AC, Ikuno AA, Burger KP, Vidal-Martins AM: Identification of Salmonella spp. isolates from chicken abattoirs by multiplex-PCR. Res Vet Sci 2006, 8 I (3):340-344.

31. Csordas AT, Barak JD, Delwiche MJ: Comparison of primers for the detection of Salmonella enterica serovars using realtime PCR. Lett Appl Microbiol 2004, 39(2): I87-193.

32. Eyigor A, Carli KT, Unal CB: Implementation of real-time PCR to tetrathionate broth enrichment step of Salmonella detection in poultry. Lett Appl Microbiol 2002, 34(I):37-4I.

33. Fey A, Eichler S, Flavier S, Christen R, Hofle MG, Guzman CA: Establishment of a real-time PCR-based approach for accurate quantification of bacterial RNA targets in water, using Salmonella as a model organism. Appl Environ Microbiol 2004, 70(6):3618-3623.

34. Fukushima H, Tsunomori Y, Seki R: Duplex real-time SYBR green PCR assays for detection of 17 species of food- or waterborne pathogens in stools. J Clin Microbiol 2003, 4I(I I):5|34-5I 46.

35. Hein I, Flekna G, Krassnig M, Wagner M: Real-time PCR for the detection of Salmonella spp. in food: An alternative approach to a conventional PCR system suggested by the FOOD-PCR project. J Microbiol Methods 2006, 66(3):538-547.

36. Hoorfar J, Ahrens P, Radstrom P: Automated 5' nuclease PCR assay for identification of Salmonella enterica. J Clin Microbiol 2000, 38(9):3429-3435

37. Khan AA, Nawaz MS, Khan SA, Cerniglia CE: Detection of multidrug-resistant Salmonella typhimurium DTI 04 by multiplex polymerase chain reaction. FEMS Microbiol Lett 2000 , I 82(2):355-360.

38. Malkawi HI, Gharaibeh R: Multiplex PCR for the direct detection of Salmonella enterica from chicken, lamb and beef food products. J Basic Microbiol 2003, 43(4):328-336.

39. Nam HM, Srinivasan V, Gillespie BE, Murinda SE, Oliver SP: Application of SYBR green real-time PCR assay for specific detection of Salmonella spp. in dairy farm environmental samples. Int J Food Microbiol 2005, I 02(2): I6I-I7I.

40. Nucera DM, Maddox CW, Hoien-Dalen P, Weigel RM: Comparison of API 20E and invA PCR for identification of Salmonella enterica isolates from swine production units. J Clin Microbiol 2006, 44(9):3388-3390.

4I. Rychlik I, van Kesteren L, Cardova L, Svestkova A, Martinkova R, Sisak F: Rapid detection of Salmonella in field samples by nested polymerase chain reaction. Lett Appl Microbiol 1999, 29(4):269-272

42. Wolffs PF, Glencross K, Norling B, Griffiths MW: Simultaneous quantification of pathogenic Campylobacter and Salmonella in chicken rinse fluid by a flotation and real-time multiplex PCR procedure. Int / Food Microbiol 2007, I I 7(I):50-54.

43. Wolffs PF, Glencross K, Thibaudeau R, Griffiths MW: Direct quantitation and detection of salmonellae in biological samples without enrichment, using two-step filtration and real-time PCR. Appl Environ Microbiol 2006, 72(6):3896-3900.

44. Kauffman F: The diagnosis of Salmonella types. Springfield III edition. 1950.

45. Altschul SF, Gish W, Miller W, Myers EW, Lipman DJ: Basic loca alignment search tool. I Mol Biol I990, 21 5(3):403-4I0.

46. Malorny B, Hoorfar J, Bunge C, Helmuth R: Multicenter validation of the analytical accuracy of Salmonella PCR: towards an international standard. Appl Environ Microbiol 2003 69(I):290-296

47. Lim $\mathrm{YH}$, Hirose K, Izumiya H, Arakawa E, Takahashi H, Terajima J, Itoh K, Tamura K, Kim SI, Watanabe H: Multiplex polymerase chain reaction assay for selective detection of Salmonella enterica serovar typhimurium. Jpn J Infect Dis 2003, 56(4): $|5|-\mid 55$

48. Soumet C, Ermel G, Rose N, Rose V, Drouin P, Salvat G, Colin P: Evaluation of a multiplex PCR assay for simultaneous identification of Salmonella sp., Salmonella enteritidis and Salmonella typhimurium from environmental swabs of poultry houses. Lett Appl Microbiol I 999, 28(2): I I3-I I7.

49. Soumet C, Ermel G, Rose V, Rose N, Drouin P, Salvat G, Colin P: Identification by a multiplex PCR-based assay of Salmonella typhimurium and Salmonella enteritidis strains from environmental swabs of poultry houses. Lett Appl Microbiol 1999, 29(I): I-6.

50. Carlson SA, Bolton LF, Briggs CE, Hurd HS, Sharma VK, FedorkaCray PJ, Jones BD: Detection of multiresistant Salmonella typhimurium DTI04 using multiplex and fluorogenic PCR. Mol Cell Probes 1999, I3(3):213-222.

51. De Medici D, Croci L, Delibato E, Di Pasquale S, Filetici E, Toti L. Evaluation of DNA extraction methods for use in combination with SYBR green I real-time PCR to detect Salmonella enterica serotype enteritidis in poultry. Appl Environ Microbio 2003, 69(6):3456-346।.

52. Herrera-Leon S, Ramiro R, Arroyo M, Diez R, Usera MA, Echeita MA: Blind comparison of traditional serotyping with three multi- 
plex PCRs for the identification of Salmonella serotypes. Res Microbiol 2007, I 58(2): I22-127.

53. Pan TM, Liu YJ: Identification of Salmonella enteritidis isolates by polymerase chain reaction and multiplex polymerase chain reaction. J Microbiol Immunol Infect 2002, 35(3): |47-I5I.

54. Pathmanathan SG, Cardona-Castro N, Sanchez-Jimenez MM, CorreaOchoa MM, Puthucheary SD, Thong KL: Simple and rapid detection of Salmonella strains by direct PCR amplification of the hilA gene. J Med Microbiol 2003, 52(Pt 9):773-776.

Publish with Bio Med Central and every scientist can read your work free of charge

"BioMed Central will be the most significant development for disseminating the results of biomedical research in our lifetime. "

Sir Paul Nurse, Cancer Research UK

Your research papers will be:

- available free of charge to the entire biomedical community

- peer reviewed and published immediately upon acceptance

- cited in PubMed and archived on PubMed Central

- yours - you keep the copyright

Submit your manuscript here:

http://www.biomedcentral.com/info/publishing_adv.asp
BiolMedcentral 